\title{
Prophylactic midazolam for prevention of post-operative nausea and vomiting following adenoidectomy or adenotonsillectomy
}

\section{Adenotonsillektomi sonrasında gelişen postoperatif bulantı kusmayı önlemede proflaktik midazolam kullanımı}

\author{
Ayça Tuba Dumanlı Özcan ${ }^{1}$, Erdal Özcan², Ebru Çanakçı, Korhan Kılıç ${ }^{4}$ \\ ${ }^{1}$ Ankara Atatürk Eğitim Araştırma Hastanesi, Anestezi ve Reanimasyon Bölümü, Ankara, Türkiye \\ ${ }^{2}$ Ankara Atatürk Eğitim Araştırma Hastanesi, Anestezi ve Reanimasyon Bölümü, Ankara, Türkiye. \\ ${ }^{3}$ Ordu Üniversitesi Tıp Fakültesi, Anestezi ve Reanimasyon Bölümü, Ordu, Türkiye \\ ${ }^{4}$ Palandöken Devlet Hastanesi, Kulak Burun Boğaz Bölümü, Erzurum, Türkiye
}

Geliş Tarihi:12.11.2016

Kabul Tarihi:15.02.2017

Doi:10.21601/ortadogutipdergisi.279714

\begin{abstract}
Aim: Postoperative nausea and vomiting (PONV) is a common complication after tonsillectomy. Midazolam is known to decrease postsurgical vomiting. In this study, we investigate the effect of intramuscular Midazolam on postoperative nausea vomiting in children undergoing adenoidectomy or adenotonsillectomy.

Material and Method: In a randomized double-blind study, we evaluated 66 healthy children, aged 5-12 years, who underwent adenoidectomy with or without tonsillectomy. Afterwards, anesthesia was induced by inhalation of sevoflurane, rocuronium bromide $0.6 \mathrm{mg} \mathrm{kg}-1$, and fentanyl $1 \mu \mathrm{g} \mathrm{kg}-1$, and anesthesia was maintained by sevoflurane for all patients. Patients were administered subcutaneous morphine $0.1 \mathrm{mg} \mathrm{kg}-1$ for postoperative analgesia. Patient's inGroup II were administered intramuscular midazolam $0.1 \mathrm{mg} \mathrm{kg}-1$. The incidence of nausea/vomiting and antiemetic requirement $0-4 \mathrm{~h}$ and $4-24 \mathrm{~h}$ post surgery was recorded. Data for postoperative vomiting were grouped into the following time periods: 0-4 and 4-24 h. Data were analyzed using a Student's t-test and chi-squared analysis.
\end{abstract}

Results: No statistically significant different was found between groups in 0-4, and 4-24 hours in terms of median VAS levels ( $\mathrm{p}=0,883$ and $\mathrm{p}=0,881$ ). Although Group II had lower incidence of nausea both in 0-4 and 4-24 hours compared to Group I, there was no statistically significant difference between the groups $(p=0,618$ and $p=0,28)$. There was no statistically significant difference between the groups in 0-4, and 4-24 hours in terms of median nausea VAS levels ( $p=0,597$ and $p=0,982)$. There was also no statistically significant difference between the groups in terms of rates of additional analgesic requirement in 24 hours, and median additional analgesic number $(\mathrm{p}=0,197$ and $\mathrm{p}=0,865$ ). Antiemetic requirement rates in 24 hours in Group II were lower at a statistically significant rate compared to Group I $(p=0,027)$. Yet, there was no statistically significant difference between the groups in terms of median antiemetic number in 24 hours $(\mathrm{p}=0,070)$.

Conclusion: For children undergoing tonsillectomy, intraoperative midazolam treatment does not provide a prophylaxis against postoperative vomiting.

Keywords: Nausea, vomiting, adenotonsillectomy, midazolam 


\section{Öz}

Amaç: Postoperatif bulantı kusma tonsillektomi sonrası en yaygın komplikasyondur. Biz de çalışmamızda adenotonsillektomi veya adenoidektomi olan çocuklarda intramuskuler midazolamın postoperatif bulantı kusmaya proflaktik etkisini araştırmayı amaçladık.

Gereç ve Yöntem: Çalışmaya 5-12 yaş arasında sağlıklı adenotonsillektomi veya sadece adenoidektomi olacak 66 çocuk randomize ve çift kör olarak çalışmaya dahil edildi. Sevofluran inhalasyonunu, 0,6 mgkg-1 rokuronyum bromid ve $1 \mu \mathrm{g} \mathrm{kg}-1$ fentanil lie anestezi indüksiyonunu takiben tüm olgularda idame sevofluran inhalasyon anestezisi ile sağlandı. Tüm hastalara subkutanöz morfin $0.1 \mathrm{mg} \mathrm{kg}-1$ postoperatif analjezi amaçlı uygulandı. Grup II'de yer alan hastalara aynı standart anestezi protokolü yanında im midazolam $0.1 \mathrm{mg} \mathrm{kg}-1$ entübasyon sonrası uygulandı. Postoperatif kusma verileri 0-4 ve 4-24. saat periotlarında gruplandırıldı. Veriler Student t-testi ve Chi-square testi ile analiz edildi.

Bulgular: Gruplar arasında 0-2 ve 2-24. saatlerde medyan VAS düzeyleri yönünden istatistiksel olarak anlamlı farklılık görülmedi ( $\mathrm{p}=0,883$ ve $\mathrm{p}=0,881)$. Gruplar arasında 24 saatte ek analjezik gereksinim oranları ve medyan ek analjezik sayısı yönünden de istatistiksel olarak anlamlı farklılık görülmedi ( $p=0,197$ ve $p=0,865)$. Grup I'e göre Grup II'de 24 saat antiemetik gereksinim oranı istatistiksel anlamlı olarak daha düşüktü $(\mathrm{p}=0,027)$.

Sonuç: Adenotonsillektomi olacak çocuklarda intraoperative sadece midazolam tedavisinin postoperatif kusmaya karşı korucu olamadığı düşüncesindeyiz.

Anahtar Kelimeler: Bulant1, kusma, adenotonsillektomi, midazolam

\section{Introduction}

Tonsillectomy is one of the most common surgical procedures performed in children, and postoperative nausea and vomiting (PONV) is a common and unpleasant complication associated with tonsillectomy $[1,2]$.

Common complications following tonsillectomy include pain, vomiting, airway obstruction, and hypoventilation [3] although postoperative vomiting is the most common side effect [4]. Patient age, surgical procedure, anesthetic protocol, dehydration, and postoperative bleeding are all associated with the incidence of postsurgical vomiting [5]. Nausea/vomiting following tonsillectomy is common; however, it is crucial because it can increase the risk of bleeding due to elevated venous pressure in the tonsil bed after tonsillectomy [6]. Furthermore, POV is one of the most common causes of delayed discharge or overnight admission in outpatient-scheduled tonsillectomy [7]. For this reason, anesthesiologists are hoping to identify novel drugs and/or techniques that minimize PONV.

Performing a minimum of two antiemetic interventions has been suggested to be the standard practice for children undergoing tonsillectomy [8], although in many institutions, including ours, costs restrict implementation of this recommendation. Furthermore, it has been suggested to introduce 3-5 interventions in patients who have moderate to high PONV risk, including 2-3 antiemetics, administration of intraoperative fluids, and using total intravenous anesthesia [6].

In our practice, we routinely use single therapy with Metoclopramide $(0.15 \mathrm{mg} \mathrm{kg}-1)$ during induction of anesthesia for POV prophylaxis. We use this regimen, as it is less costly than 5-HT3 antagonists.

Because of the side effects and disadvantages of other antiemetic agents, midazolam is used at our clinic since it is readily available. Midazolam decreases nausea and vomiting compared to placebo, and is used for the prophylactic treatment of postoperative nausea/vomiting. Midazolam $2 \mathrm{mg}$, when administered 30 minutes before the end of surgery, was as effective against PONV as ondansetron $4 \mathrm{mg}$ [9]. combined administration of haloperidol $2 \mathrm{mg}$ plus midazolam $2 \mathrm{mg}$ significantly reduced PONV better than using each drug alone in patients who underwent middle ear surgery under general anesthesia [10]. Midazolam and morphine are administered IV. PCA, and the treatment application are reported [11]. Huh et al. administered midazolam $0.4 \mathrm{mg}$ and morphine 
$1 \mathrm{mg}$ in combination, and reported that the incidence of nausea/vomiting was lower in such subjects than those who only received morphine [12].

To date, no study has explored the efficacy of intramuscular doses of midazolam intraoperatively for prevention of $\mathrm{POV}$ in either pediatric or tonsillectomy surgical populations. The purpose of this prospective randomized, and double blind study was to assess the ability of an intraoperative intramuscular Midazolam, in combination with morphine, to reduce POVN in children undergoing tonsillectomy.

\section{Material and Method}

The Ethics Committee, Erzurum Regional Training and Research Hospital approved all procedures. Sixty-six children, aged 5-12 years, were enrolled in this study. Verbal and written informed consent was received from the patients' parents. The parents of these children enrolled for the study were given verbal and written information about the study, and their written consent was obtained. The patients and parents were made aware of the two different study groups, but were not told in which group the child would be included. All subjects had an ASA physical status of II, or I and were to undergo tonsillectomy or adenotonsillectomy. The study was designed as a randomized, patient-parent, and investigator-blinded study. Only the anesthesiologist was aware of the treatment group. Children with systemic disease or who received antiemetic, antihistamine, or steroid treatment within 24 $\mathrm{h}$ prior to the surgery or had an allergy to any of the study drugs were excluded from the study. Solid foods were permitted $6 \mathrm{~h}$ and clear fluids were permitted $3 \mathrm{~h}$ before the scheduled surgery.

Patients in Group 1 were administered our hospital's standard anesthetic protocol: inhalation induction via sevoflurane intravenous cannulation, intubation under rocuronium bromide $0.6 \mathrm{mg} \mathrm{kg}-1$, and Fentanyl $1 \mu \mathrm{g} \mathrm{kg}-1$, and maintenance with sevoflurane and nitrous oxide. After the intubation all patients received subcutaneous morphine $0,1 \mathrm{mg} \mathrm{kg}-1$ for postoperative analgesia. Patients in Group II were administered the same standard anesthetic protocol plus im. Midazolam $0.1 \mathrm{mg} \mathrm{kg}-1$ after the intubation. Intravenous fluid (Ringer's lactate) management was standard, and included intraoperative fluid maintenance and the replacement of fluid deficits in cases with insufficient oral fluid intake. The children subsequently received $1500 \mathrm{ml} / \mathrm{m} 224 \mathrm{~h}$ until they could orally ingest sufficient fluids. Gastric aspiration was performed before cutting anesthetic gases. Extubation was performed via administration of Neostigmine $60 \mu \mathrm{g} \mathrm{kg}-1$ and Atropine $20 \mu \mathrm{g} / \mathrm{kg}-1$ in patients with spontaneous breathing.

Patients were randomly assigned to one of the two groups using a sealed envelope technique before anesthesia induction. Patients in Group II ( $\mathrm{n}=33)$ received $0,1 \mathrm{mg} /$ kg-1 Midazolam after intubation.

Nurses and the doctor of the Department of Otolaryngology, who were blinded to group assignment, recorded Nausea/ vomiting in patients during the postoperative service; according to postoperative $0-4 \mathrm{~h}$ and $4-24 \mathrm{~h}$. Retching was recorded as vomiting. Reports of vomiting were obtained by interviewing the parent and child. Data for POV were grouped into the following time periods: $0-4$ and 4-24 h. When retching or vomiting occurred more than twice in $30 \mathrm{~min}$, intravenous Metoclopramide $0.15 \mathrm{mg} / \mathrm{kg}-1$ was administered for Acute antiemetic rescue. Patients that were able to receive medicines orally were administered Paracetamol $20 \mathrm{mg} / \mathrm{kg}-1$ for pain. The first dose was administered iv.in the operating room. The patients with nausea/vomiting were administered IV before oral intake. Patient gender, age, weight, duration of surgery, duration of anesthesia, vomiting, and antiemetic and analgesic requirements were recorded.

\section{Sample Size Calculations}

It was envisaged to include at least 33 subjects in each group in order to test the statistical significance of a minimum $30 \%$ of difference between the groups in terms of nausea incidence at a significance level of $5 \%$ and power level of $80 \%$. The information about the difference of $30 \%$ was obtained from both the study and our clinical experience. Sample size calculations were conducted through $G^{*}$ Power 3.0.10 package software.

\section{Statistical Analysis}

The analysis of the data was conducted through SPSS for Windows 17.0 package software. Kolmogorov Smirnov's test was used to investigate whether discrete numerical variables are distributed close to a normal distribution. Descriptive statistics were indicated as median (minimummaximum) for discrete numerical variables, and nominal 
variables were indicated as the number of subjects and (\%). The significance of the difference between the groups in terms of median values was examined through Mann Whitney $U$ test. The nominal variables were assessed through Chi-square or Fisher's exact probability test. Results were considered statistically significant for $p<0.05$.

\section{Results}

The study included 66 patients. There was no statistically significant difference between the groups in terms of median age, gender distribution, median body weight, duration of operation, anesthetic duration, and the distribution of operation types $(\mathrm{p}>0.05)$ (Table1).

There was no statistically significant difference between the groups in terms of median VAS levels in 0-4 and 4-24 hours ( $\mathrm{p}=0.883$ and $\mathrm{p}=0.881$ ). Although Group II had lower incidence of nausea both in 0-4 and 4-24 hours compared to Group I, there was no statistically significant difference between the groups ( $\mathrm{p}=0.618$ and $\mathrm{p}=0.284$ ). There was no statistically significant difference between the groups in 0-4, and 4-24 hours in terms of median nausea VAS levels $(\mathrm{p}=0.597$ and $\mathrm{p}=0.982$ ). There was also no statistically significant difference between the groups in terms of rates of additional analgesic requirement in 24 hours, and median additional analgesic number $(\mathrm{p}=0.197$ and $\mathrm{p}=0.865)$. Antiemetic requirement rates in 24 hours in Group II were lower at a statistically significant rate compared to Group I $(p=0.027)$. Yet, there was no statistically significant difference between the groups in terms of median antiemetic number in 24 hours $(\mathrm{p}=0.070)$ (Table 2$)$.

Table 1: Demographic and clinical features of the subjects by groups

\begin{tabular}{|l|l|l|c|}
\hline \multicolumn{1}{|c|}{ Variables } & $\begin{array}{c}\text { Group I } \\
(\mathbf{n = 3 3 )}\end{array}$ & $\begin{array}{c}\text { Group II } \\
(\mathbf{n = 3 3 )}\end{array}$ & $\begin{array}{c}\text { P } \\
\text { value }\end{array}$ \\
\hline Age (years) & $6(2-12)$ & $6(3-11)$ & $0,679 \dagger$ \\
\hline Gender & & & $0,196 \dagger$ \\
\hline Male & $24(\% 72,7)$ & $19(\% 57,6)$ & \\
\hline Female & $9(\% 27,3)$ & $14(\% 42,4)$ & \\
\hline Body weight $(\mathrm{kg})$ & $20(10-46)$ & $20(10-40)$ & $0,937 \dagger$ \\
\hline Duration of operation (mins) & $25(10-35)$ & $25(15-45)$ & $0,218 \dagger$ \\
\hline Duration of anesthesia (mins) & $30(15-45)$ & $30(20-50)$ & $0,257 \dagger$ \\
\hline Type of operation & & & $0,447 \dagger$ \\
\hline A & $11(\% 33,3)$ & $14(\% 42,4)$ & \\
\hline AT & $22(\% 66,7)$ & $19(\% 57,6)$ & \\
\hline$\dagger$ Mann Whitney U test, + Chi-square test. &
\end{tabular}


end of surgery, and this protocol was as effective against PONV as ondansetron $4 \mathrm{mg}$ [9]. The post-tonsillectomy PONV incidence may reach high values up to $50-80 \%$ [12]. Bolton $\mathrm{C} \mathrm{M}$ et al. [13] report the incidence of postoperative nausea and vomiting as higher than $70 \%$ in the cases of absence of prophylaxis. Erk et al. [14] administered ketamine and midazolam to pediatric patients undergoing adenotonsillectomy operation, and reported that the incidence of nausea/vomiting was $67.9 \%$ in the patients that received ketamine only, versus $32.1 \%$ in the patients that received ketamine and midazolam.

Midazolam is a water-soluble benzodiazepine that is metabolized quickly because of its imidazole ring, amnesic property of which is at the forefront [15]. Midazolam dose of 50-75 microgram $/ \mathrm{kg}$ has been recommended for prophylactic antiemetic use [16]. Another study reported that $75 \mathrm{microgram} / \mathrm{kg}$ of midazolam injected into patients who had undergone thyroidectomy was as effective as $4 \mathrm{mg}$ of ondansetron in preventing PONV, without creating any delay in the recovery time [17]. Doses used in the present study were, however, lower than those recommended for sedation, and the antiemetic effect of midazolam has already been shown to last longer than the effects of sedation [18]. It was reported that midazolam administered 30 minutes before the end of surgery was more effective in decreasing the incidence of PONV than midazolam given 15 minutes before induction of anesthesia [19]. Therefore, 100 microgram of midazolam was administered immediately after the induction.

Incontrasttootherparenteral formulations of benzodiazepines, intramuscular midazolam is rapidly absorbed; with peak serum concentrations achieved at $17.5 \pm 6.5$ to $25 \pm 23 \mathrm{~min}$ [20]. The postulated antiemetic mechanism of midazolam includes glycine mimetic inhibitory effects, adenosinergic effects, and inhibition of dopamine release [21]. Midazolam may also affect striatal dopamine release, and the anesthetic actions of midazolam are partially related to inhibition of dopamine neuron A1 activity [22].

It is reported that midazolam reduces nausea/vomiting by decreasing the release of dopamine in the chemoreceptor trigger zone and it reuptakes the adenosine. Midazolam moderates adenosine-mediated dopamine synthesis in the chemoreceptor trigger zone, in addition to its postsynaptic effects. It prevents $5 \mathrm{HT} 3$ release and dopaminergic neuronal activity by adhering to aminobutyric acid receptors [23]. However, intraoperative opioids are known to be a risk factor for postoperative nausea/vomiting. In another study [24], midazolam and remifentanil were administered in combination, and though not significantly different, the incidence of nausea/vomiting in the group administered only midazolam was a little lower than the one in the group that received midazolam and remifentanil. The similarity between the findings in both groups was attributed to the interaction of the 2 drug groups in the chemoreceptor trigger zone. In the present study, morphine was combined with midazolam. In spite of being not significantly different, the use of morphine combined with intramuscular midazolam was associated with a lower incidence of nausea/vomiting than the use of morphine alone.

The limitation of this present study is that we were unable to conduct continuous infusion due ethical concerns and the risk of respiratory depression since the patients were children, although the difference was indicated in studies [25] where continuous infusion was conducted.

\section{Conclusion}

In conclusion, we did not find an effect of midazolam, which prevents postoperative nausea vomiting. We are of the opinion that there is a need for more detailed research and clinical studies on the collocation of opioids and midazolam for controlling nausea vomiting in postoperative period, as well as on drug doses, the way of their administration, action mechanism, and their interactions with each other.

\section{Declaration of conflicting interests}

The author declared no conflicts of interest with respect to the authorship and/or publication of this article.

\section{References}

1. Guida RA, Mattucci KF. Tonsillectomy and adenoidectomy: an inpatient or out patient procedur? Laryngoscope 1990;100:491-3.

2. Carithers JS, Gebhart DE, Williams JA. Postoperative risks of pediatric tonsilloadenoidectomy. Laryngoscope 1987;97:422-9.

3. Fazi L, Jantzen EC, Rose JB, Kurth CD, Watcha MF. A comparison of oral clonidine and oral midazolam as preanesthetic medications in the pediatric tonsillectomy patient.Anesth Analg 2001;92:56-61. 
4. Apfel CC, Läärä E, Koivuranta M, Greim CA, Roewer N. A simplified risk score for predicting postoperative nausea and vomiting: conclusions from cross-validations between two centers. Anesthesiology 1999;91:693-700.

5. Baines D. Postoperative nausea and vomiting in children. Pediatric Anaesth.1996;6:7-14.

6. Mowafi AH, Telmessani L, Ismail S A, Naguib MB. Preoperative lornoxicam for pain prevention after tonsillectomy in adults. Journal of Clinical Anesthesia 2011;23:97-101

7. Anderson BJ, Ralph CJ, Stewart AW et al. The dose-effect relationship for morphine and vomiting after day-stay tonsillectomy in children. Anaesth Intensive Care 2000; 28:155-60.

8. Herreen PG, Wiese MC. Concealed post-tonsillectomy haemorrhage associated with the use of the antiemetic tropisetron. Anaesth Intens Care 2001;29:421-2.

9. Gan TJ, Diemunsch P, Habib AS et al. Consensus Guidelines for the Management of Postoperative Nausea and Vomiting. Anesthesia \& Analgesia 2014;118:85-113.

10. Azim H, Mohammadreza S, Gholamreza K, Fatemeh M. Prophylactic administration of haloperidol plus midazolam reduces postoperative nausea and vomiting better than using each drug alone in patients undergoing middle ear surgery. Saudi J Anaesth 2012;6:145-51.

11. Huh BK, Jung S, White W, Jeon Y. Antiemetic effect of midazolam added to patient-controlled analgesia after total abdominal hysterectomy. Anaesth Intensive Care 2010 May;38: 481-5.

12. Furst SR, Rodarte A. Prophylactic antiemetic treatment with ondansetron in children undergoing tonsillectomy. Anesthesiology 1994;81:799-803.

13. Bolton CM, Myles PS, Nolan T, et al. Prophylaxis of postoperative vomiting in children undergoing tonsillectomy: a systematic review and meta-analysis. Br J Anaesth 2006; 97:593-604.

14. Erk G, Örnek D, NF Dönmez, Taşpınar V. The use of ketamine or ketamine-midazolam for adenotonsillectomy. Int $\mathrm{J}$ Pediatr Otorhinolaryngol 2007;71:937-41.

15. Fujii Y, Itakura M. A prospective, randomized, double blind, placebo-controlled study to assess the antiemetic effects of midazolam on postoperative nausea and vomiting in women undergoing laparoscopic gynecologic surgery. Clin Ther 2010;32:1633-7.

16. Splinter WM, MacNeill HB, Menard EA, et al. Midazolam reduces vomiting after tonsillectomy in children. Can J Anaesth 1995;42:201-3.
17. Ha JH, Kwak KH, Seo JW, et al. Effectiveness of ondansetron and midazolam in the prevention of PONV after thyroidectomy. Korean J Anesthesiol 2007;53:344-9.

18. Unlugenc H, Guler T, Gunes Y, et al. Comparative study of the anti-emetic efficacy of ondansetron, propofol and midazolam in the early postoperative period. Eur J Anaesthesiol 2004; 21:60-5.

19. Safavi MR and Honarmand A. Low dose intravenous midazolam for prevention of PONV, in lower abdominal surgery - preoperative vs intraoperative administra- tion. Middle East J Anesthesiol 2009;20:75-81.

20. Patel SI, Birnbaum AK, Cloyd JC, Leppik IE. Intravenous and Intramuscular Formulations of Antiseizure Drugs in the Treatment of Epilepsy.CNS Drugs. 2015 Dec;29:1009-22. doi:10.1007/ s40263-015-0289-0.

21. Kim WJ, Kang H, Shin HY, et al. Ramosetron, midazolam, and combination of ramosetron and midazolam for prevention of postoperative nausea and vomiting: a prospective, randomized, double blind study. J Int Med Res 2013 Aug;41:1203-13.

22. Park EY, Lee SK, Kang MH, et al. Comparison of ramosetron with combined ramosetron and midazolam for preventing postoperative nausea and vomiting in patients at high risk following laparoscopic gynaecological surgery. J Int Med Res 2013 Jun;41:654-63.

23. Honarmand A, Safavi M, Khalili G, Mohammadnejad F. Prophylactic administration of haloperidol plus midazolam reduces postoperative nausea and vomiting better than using each drug alone in patients undergoing middle ear surgery. Saudi J Anaesth 2012;6:145-51

24. Jang JS, Lee JH, Lee JJ, et al. Postoperative nausea and vomiting after myringoplasty under continuous sedation using midazolam with or without remifentanil. Yonsei Med J 2012;53:1010-13.

25. Sanjay OP, Tauro DI. Midazolam: an effective antiemetic after cardiac surgery - a clinical trial. Anesth Analg 2004;99:339-43.

Corresponding Author: Ayça Tuba Dumanlı Özcan, Ankara Atatürk Eğitim Araştırma Hastanesi,

Anestezi ve Reanimasyon Bölümü, -1. Kat Ameliyathane, Bilkent, Ankara, Türkiye

E-mail: draycaozcan@gmail.com 